\title{
The Transformation of "Zār" from a Therapeutic Ritual into a Musical Performance by Mazaher Ensemble
}

Marwa Youssef Al-Sayad*

\section{$\underline{\text { Introduction }}$}

Many cultures around the world use drumming and dancing rituals as healing processes; half of these cultures believe in some form of spirit possession and use these rituals to connect with higher spiritual entity. Among these healing rituals we find Vimbuza ${ }^{1}$, Shamanism ${ }^{2}$, and Zār .

$Z \bar{a} r$ ceremonies are ancient healing practices that were found widely in Eastern Africa; in Egypt, Sudan, Somalia, Ethiopia and throughout the Arabian Gulf. Zār rituals were used to heal individuals who are possessed by spirits or as called in Egypt Jinn or Asyad (Masters). The ritual has been misperceived as a form of exorcism. However, the aim of Zār is to harmonies the inner lives of the participants, or as the practitioners intend, to create harmony between the possessed person and her "master".

Music is an important aspect of Zār ritual, communication with the unseen spirits is driven by the insistent and varied drum rhythms and by the energetic movements of the participants in an intense rhythmic interaction which can lead to an altered state of consciousness and, even, trance. ${ }^{3}$

Mazaher ensemble is one of the famous ensembles in Egypt that continues to uphold the traditions of Zār by performing the vigorous singing and dancing routine, although in a performative context, without demons being evicted. Mazaher ensemble is remarkably performing the Zār every week with powerful Sufi singing and rich poly-rhythmic drumming.

\footnotetext{
* Teacher at Theory and Composition department, Faculty of Music Education, Helwan University.

${ }^{1}$ Vimbuza is a healing dance ritual popular among the Tumbuka people living in northern Malawi.

2 Shamanism is a practice that involves a practitioner reaching altered states of consciousness in order to perceive and interact with what they believe to be a spirit world and channel these transcendental energies into this world.

3 The ritual - https://egyptmusic.org/en/Musicians/mazaher/

Retrieved on February 12nd/ 2020 at 3:00pm
}

مجلة علوم وفنون الموسيقى - كلية التربية الموسيقية - المجلد Y؟ - عدد خاص "الموسيقى وهوية الشعوب" - أغسطس اب.rمر 


\section{Problem formulation}

Rite of Zār is one of the ancient rituals rooted in the Egyptian culture, but due to certain changes of the social and cultural construction of the Egyptian society, Zār gradually disappeared as a ritual and begin to transform as a performance.

\section{Objectives of the paper}

This paper aims to

1- Identifying Zār rituals and its origins historically, and addressing how singing, drumming and dancing contribute to those healing rituals.

2- Describing the Main features of Zār music and songs.

\section{Questions of the research}

The paper further seeks answers to questions such as:

1- What is Zār?

2- What are the main features of Zār music and songs?

3- How did Mazaher ensamble manage to transform the "Zār" from a therapeutic ceremony into a Musical Ritual?

4- What are the characteristics of Zār music that causes the state of trance?

\section{Research Methodology}

- Analytical and descriptive

\section{Definition of terms}

Zār: an Amharic word refers to both type of spirit and to various practices and rituals associated with those spirits. ${ }^{1}$

Dakka: the translation of the word Dakka in English is "beat". It's the name that Zār practitioners use to refer to Zār songs. And that's because of the major role of beating on percussion instruments in these songs. ${ }^{2}$

${ }^{1}$ Heike Behrend, Spirit Possession, Modernity \& Power in Africa (Madison: The university of Wisconsin Press, 1999)

${ }^{2}$ Adil Al-Ulaymi, al-Zār wa masrah al-tuqus. (Cairo: General Egyptian Book Organization, 1993) p. 175

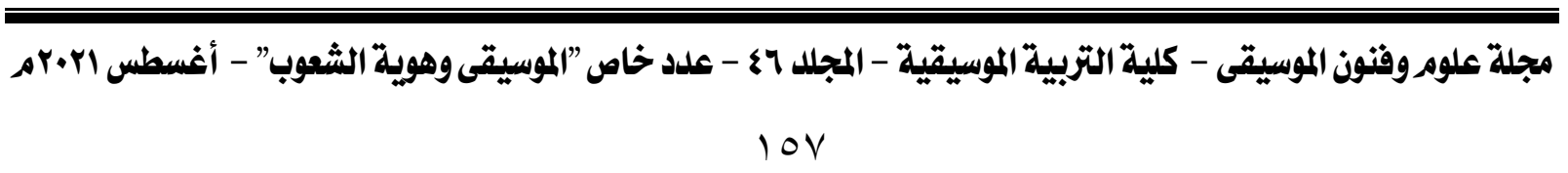


Entrainment: the process by which the powerful rhythmic vibrations of one object are projected upon a second object with a similar frequency, thereby causing that object to vibrate in resonance with the first object. ${ }^{1}$

Trance: an altered state of consciousness characterized by decreased awareness of and responsiveness to stimuli and an apparent loss of voluntary power. ${ }^{2}$

\section{First section: Historical Background}

\section{The origins of the Zār}

The origins of the word Zār is obscure and there are many opinions concerning the linguistic origins of the word Zār; Enrico Cerulli $(1898-1988)^{3}$ suggests that the word Zār is derived from the Amharic word 'Jar' from a Cushitic language specifically in $\mathrm{Agaw}^{4}$. The word Jar refers to the God of heaven. ${ }^{5}$ The Encyclopedia of Islam supports the contention that the word Zār is Ethiopian in Origin, and Simon Messing states that the Zār cult is highly developed in Northern Ethiopia with its center in the town of Gondar. ${ }^{6}$

The earliest mention of a Zār ritual dates to the first half of the nineteenth century and it emphasizes the previous believe that the origin of the word Zār as well as the ritual itself- is Ethiopia. In 1839, two evangelists of the Church Mission Society, John Lewis Karpf and Charles William Isenberg, witnessed a possession ceremony held in a home in highland Ethiopia very similar to modern descriptions of Zār ritual. They stated that "The Gallas and all of the people of Gurague and Shoa believe that there are eighty-eight spirits, which they call Sarotsh (in the singular 'Sar')"7

Taghi Modarressi ${ }^{8}$ who is writing about Persian Zār suggests Persian origin of the cult and that the word Zār as a noun means 'mourning' or 'crying' while as

\footnotetext{
${ }^{1}$ Mitchell L. Gaunor, The Healing Power of Sound. (London: Shambhala, 2002) p.64

${ }^{2}$ APA Dictionary of Psychology (Washington: American Psychological Association 2020), "Trance", https://dictionary.apa.org/trance

${ }^{3}$ An Italian scholar of Somali and Ethiopian studies, a governor and a diplomat.

${ }^{4}$ An ethnic group inhabiting Ethiopia

${ }^{5}$ Hager El El Hadidi , Zār: Spirit Possession, Music, and Healing Rituals in Egypt, (Cairo: The American University in Cairo Press, 2016) p.36

${ }^{6}$ Hani Fakhouri, The Zār Cult in an Egyptian Village. Anthropological Quarterly Vol. 41, No. 2 (Apr., 1968), p. 49

7 Scott Reese, Imperial Muslims: Islam, Community and city in the Indian Ocean, 1839-1937. (Edinburgh: Edinburgh University Press, 2018) p.115

${ }^{8}$ An Iranian child psychiatrist and author
}

مجلة علوم وفنون الموسيقى - كلية التربية الموسيقية - المجلل ج؟ - عدد خاص "الموسيقى وهوية الشعوب" - أغسطس ا.r.rم 
an adjective it means 'thin' or 'weak'. ${ }^{1}$ While John walker states that the word could have been derived from the town of Zāra in northern Iran, or is derived from the Arabic word zeyarah which means visitation, as persons possessed by demons are said to have been "visited" by spirits. ${ }^{23}$

Other studies suggest that the term Zār may have been borrowed from old Hebrew. The long-established presence of Jewish communities and their historic influence as merchants and craftsmen in the Red Sea region make this theory plausible. In Modern Hebrew, the word Zār means 'stranger' or 'Foreigner', and the Hebrew etymology in derived from the root word $z w r$, which means 'to turn aside, deviate, go away', and its participle $z r$, the 'one who distances or removes himself'. ${ }^{4}$

To conclude, the term $Z \bar{a} r$ refers to both type of spirit and to various practices and rituals associated with those spirits; it also encompasses several different ways or organized sets of practices. ${ }^{5}$ It is curtail to understand that most people think that Zār is about exorcism, while Zār rituals are in fact about possession. It is a healing ritual that aims to create harmony between the possessed person and her 6 "master".

\section{Zār Ritual in Egypt}

Despite the uncertainty surrounding the origins of the term Zār, there are many indications that Zār trickled from Abyssinia. As mentioned before, the earliest mention of a Zār ritual dates to the first half of the nineteenth century when the two evangelists of the Church Mission Society, Karpf and Isenberg, witnessed a possession ceremony held in a home in highland Ethiopia. Their Amhara interpreter explained what they had observed that The Gallas and all of the people of Gurague and Shoa, who are smokers, believe that there are eightyeight spirits, which they call Sarotsh (in the singular 'Sar') these spirits are said to walk about and inflict men with sickness; and hence, when such persons feel

\footnotetext{
${ }^{1}$ El Hadidi, Op. Cit. p.36

${ }^{2}$ Fakhouri, Op. Cit. p. 49

${ }^{3}$ El-Sayed El-Aswad, Religion and Folk Cosmology: Scenarios of the Visible and Invisible in Rural Egypt (Greenwood Publishing Group, 2002) p. 141

${ }^{4}$ El Hadidi, Op. Cit. p.36

${ }^{5}$ Behrend, Op. Cit

${ }^{6}$ Most participants in the Zār ceremony are women; rarely do men attend except in their capacity as professional musicians

مجلة علوم وفنون الموسيقى - كلية التربية الموسيقية - المجلد ج؟ - عدد خاص "الموسيقى وهوية الشعوب" - أغسطس ا.r.rم 
sick, they take their refuge in superstitious means. By smoking and singing, moving their body, and particularly by offering a hen to the Sar, they imagine that they can frighten away the bad spirit and secure themselves against being sick. The Sarotsh are divided into two parties, each having its Alaca or head. One Alaca is called Mama who has forty-four Sarotsh under his command, and the name of the other Alaca is Warrer and has the same number of Sarotsh under him. Each Sar has a particular name. ${ }^{1}$

The exact year of the introduction of Zār to Egypt is obscure, but most researchers agree that it was some time during the late eighteenth or early nineteenth century by female Ethiopian slaves (many of whom were Gallas) who entertained the ladies of the wealthy families. ${ }^{23}$

The basic outlines of the Zār and similar rituals are structurally the same everywhere they are found. Individuals in communities throughout the region in which Zār is practiced might find themselves in a state of 'dis-ease', with symptoms that range from diagnosable allopathic illness to affective disorders that exhibit characteristics of depression, anxiety, uncontrolled violence or suicidal tendencies. The affected individual may seek treatment from conventional allopathic medical doctors and hospitals but fail to obtain relief from his or her ailment; he or she then might seek out a Zār practitioner. ${ }^{4}$

Popular belief has it that every place is inhabited by a spirit of its own, the Egyptians call them Asyad (Masters) or Jinn ${ }^{5}$, According to Islamic belief, Jinn are real creatures that form a world other than that of mankind, capable of causing physical and mental harm to human beings. ${ }^{6}$

\footnotetext{
${ }^{1}$ Charles William Isenberg, Johann Ludwig Krapf, James MacQueen, Journals of the Rev. Messrs Isenberg and Krapf, Missionaries of the Church Missionary Society: Detailing Their Proceedings in the Kingdom of Shoa, and Journeys in Other Parts of Abyssinia, in the Years 1839, 1840, 1841, and 1842. (Cambridge University Press, Oct 27, 2011) p.117

${ }^{2}$ Fakhouri, Op. Cit. p. 49

3 Harald Aspen, Amhara Traditions of Knowledge: Spirit Mediums and Their Clients. (Wiesbaden: Otto Harrassowitz Verlag, 2001) p. 36

${ }^{4}$ William O. Beeman, The Zār in the Persian Gulf Performative dimensions, Anthropology of the Contemporary Middle East and Central Eurasia - December 2015. P.3

${ }^{5}$ they are not called spirits because spirits are the souls of dearly departed relatives and friends who only come to them in their dreams

6 Najat Khalifa, Tim Hardie, Possession and jinn, J R Soc Med. 2005 Aug; 98(8): 351-353
}

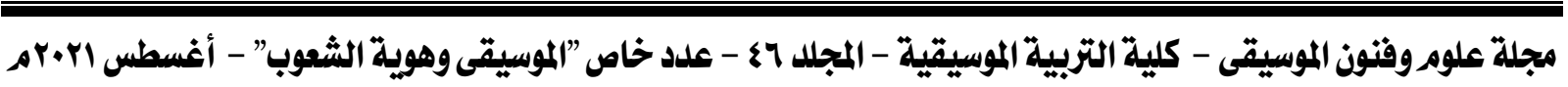


The ceremony is led by a woman known as the Kodya ${ }^{1}$ a word of an Amharic Origin that refers to "the wise old woman" so she is also sometimes called the Sheikha or Rayyesa "chief". She is considered to be the link or the translator between the two worlds, the world of humans and the world of Jinn.

Zār rituals in Cairo are classified by ritual specialists in two major ways. The first type is a ritual called 'al-sakt' which means in silence, referring to the absence of music. The second type is called 'drummed Zār' 'dakket Zār', and it includes music and songs ${ }^{2}$. The second mentioned type is our concern in this research.

\section{Dakket Zār}

The musical Zār is characterized by the presence of professional musicians who specialize in a variety of Zār ritual singing. Zār ritual singing entices the spirits to manifest themselves in the bodies of the dancing devotees, mainly through possession trances. Zār music is performed in two arenas: the first is $\mathrm{Al}$ Hadra which can also be categorized as a public Zār. Al-Hadra is a weekly gathering conducted mostly every Friday with the exception of the month of Ramadan since according to the interpretation of Qur'an the evil spirits disappear during Ramadan. It is hosted in the home of a Zār ritual leader 'sheikh or sheikha' and limited to the musical part of spirit placation. ${ }^{3}$

the second arena is in Zār initiation ceremonies that are called farah el-Zār 'Zār celebration', these are the private ceremonies that take place in the home of the possessed woman and during the initiation ceremony she will hopefully fall into a trance, allowing the Zār spirit to enter her body and reveal its identity and demands. That only happens when the musician play the right rhythmic cycles 'dakka' and sing the right songs for that particular spirit to respond to. After the initiation ceremony, the host will always be possessed by the spirit but in a more controlled way that does not seriously interfere with her daily life. ${ }^{4} 5$

\footnotetext{
${ }^{1}$ Some writings refers that Kodya means a "drummer"

${ }^{2}$ El Hadidi, Op. Cit. p.36

${ }^{3}$ Fakhouri, Op. Cit. p. 49

${ }^{4}$ Joseph P. Laycockm Spirit Possession around the World: Possession, Communion, and Demon Expulsion across Cultures (California: ABC-CLIO, 2015) p.380

${ }^{5}$ Pietro Toggia, Abebe Zegeye, Ethiopia in Transit: Millennial Quest for Stability and Continuity. (New York: Routledge, 2011)
}

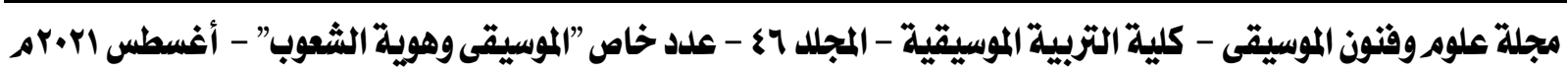


Each Zār ceremony used to have its own musical troupes who played different styles of music and instruments. However, during the second half of the twentieth century there was a mixing of musical styles and pantheons, particularly for the most popular Zār spirits. With time, some musical groups totally disappeared, yet, their most popular spirits with their particular songs and rhythms were adopted by other musical groups. Today there are three Zār musical groups in Egypt: the upper Egyptian "Sa'idi", the Tambura or Sudani, and Abul Gheit.

Upper Egyptian group used to consist only of female musicians, originally often of gypsy origins, who migrated from the Upper Egypt to Cairo with their styles of music and Zār beliefs. With time, they have incorporated many of the songs and traditions of other local woman's groups from Cairo.

Tambura group was originally made up of migrants from Sudan who settled in Egypt during Anglo-Egyptian rule. ${ }^{1}$ In addition, Abul Gheit group, originally from Abul Gheit an island near Qaliyubia, they are specialized in Zikr. ${ }^{2}$

\section{Musical construction of the Zār Ritual}

Music - and singing in particular- is an important aspect of the Zār ritual. After preparing the site for the ritual with all the details required like the table covered with a usually white piece of cloth, the special candles all around it, the costumes, the special Zār incense and the offerings, the actual ritual then starts with drumming and singing and dancing.

It is during the intense drumming and the accelerating tempo and aggressive dance, when the ritual reaches its climax and the state of trance occurs. In Zār rites, music and dance are meant for the purposes of healing not for entertainment (despite the fact that they may entertain at certain points in time).

Nowadays, the practiced ritual of Zār became very limited, and many songs have been forgotten as the practice of Zār in Egypt has nearly vanished. Only few persons in all of Egypt still have knowledge of the musical legacy of the

\footnotetext{
1 In January 1899, an Anglo-Egyptian agreement restored Egyptian rule in Sudan but as part of a condominium, or joint authority, exercised by Britain and Egypt. The agreement designated territory south of the twentysecond parallel as the Anglo-Egyptian Sudan (1899-1955).

${ }^{2}$ El Hadidi, Op. Cit. p.36
}

مجلة علوم وفنون الموسيقى - كلية التربية الموسيقية - المجلل جا؟ - عدد خاص "الموسيقى وهوية الشعوب" - أغسطس اr.rم. 
Zār and continue to practice this tradition. One of the famous ensembles in Egypt that continues to uphold the traditions of the Zār is "Mazaher" ensemble.

\section{Mazaher Ensamble}

Mazaher is an ensemble that was founded in 1999 by (Makan) ${ }^{1}$ and its owner Dr.Ahmed el-Maghraby and the members who are the last remaining Zār practitioners in Egypt. After interviewing Dr.Ahmed el-Maghraby about the musicians of Mazaher, he said the following about them:

- Madiha - Omm Sameh is the leader of Mazaher ensemble. She is a 70 years old Kodya and she is considered to be the oldest female Zār leader in Egypt. She inherited this legacy from her mother, as she started attending and learning Zār rituals when she was only 11 years old. Omm Sameh playes duff, shakhashekh, and she is the main singer.

- Om Hassan: tabla player and singer

- Sabah: duff, tura player and singer

- Raafat Farrag: tambura, hana player and singer

- Araby: mazhar, mangour player and singer

Musicians of Mazaher gathered what is left of Zār ritual music and represented it in a different way. They transformed the therapeutic ritual of Zār into a pure musical performance, and adding a whole new perspective to the musical elements of that ancient folkloric ritual.

The music they are performing are inspired by the three previously mentioned styles of the Zār tradition practiced in Egypt: Upper Egyptian Zār, the Sudanese or African Zār, and Abul Gheit Zār.

\section{1- Upper Egyptian Zār}

This type of Zār is the "Śa ‘īdī" or "Egyptian Zār" which is mostly performed by women. The leader - Madiha- starts singing solely and the female singers answer her while playing their percussion instruments. Two male players are only drumming but not participating in the singing.

The Zār songs that they perform in this category are many, for example:

- Hawanim al-Habash (Habash Ladies)

${ }^{1}$ The Egyptian Center for culture and Art in Saad Zaghloul Street in Cairo

مجلة علوم وفنون الموسيقى - كلية التربية الموسيقية - المجلد ج؟ - عدد خاص "الموسيقى وهوية الشعوب" - أغسطس ا.r.rم 
- Mumma (or Mamma)

- Hakim basha (Sir Doctor)

- Tabour ya basha tabour bara ( A line of people sir, A line of people outside)

- Rumi Nagdi and Marouma

- Yawra ya amar leih betikhtifi (Beautiful Yawra why are you scared)

The previous songs -as can be seen in their titles- are all about Asyad or spirits' names. For example Hakim basha is a spirit that has the character of a doctor, Mumma is the oldest known spirit in Egypt and Ethiopia and he is one of the two chiefs or leader of Zār spirits "Zārotsh". ${ }^{1}$

Each spirit has a certain beat which attracts; the rhymical pattern drummed is what makes the spirit appear of possessed person's body.

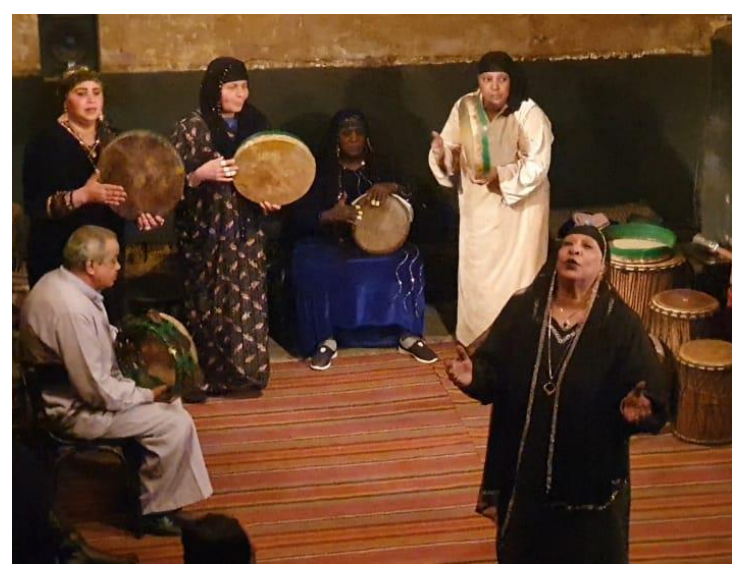

Figure (1) performance of 'Upper Egyptian Zār' -Mazaher EnsambleMAKAN- Cairo 2020

\section{Musical Instruments}

In this type of Zār songs, the musicians depend on the drum instruments duff, mazaher and häna as well as the cymbals türa and the maracas shakhāshīkh. ${ }^{2}$

\footnotetext{
1 Richard Natvig. "Oromos, Slaves, and the Zār Spirits: A Contribution to the History of the Zār Cult." The International Journal of African Historical Studies 20, no. 4 (1987): 669-89. Accessed January 19, 2021. doi:10.2307/219657

${ }^{2}$ Ahmed El Maghraby, My journey with the Zār People and Mazāher Ensemble (Cairo: Egyptian center for culture and Art, 2020)
}

مجلة علوم وفنون الموسيقى - كلية التربية الموسيقية - المجلد جاء - عدد خاص "الموسيقى وهوية الشعوب" - أغسطس اr.rه. 
Duff (or Tar): is a wide circular wooden frame, with parchment of goat skin tightened on one side. Sometimes it is called (plane mezhar) because it looks like mezhar but without the Cymbals. ${ }^{1}$ The duffl Tar is considered the main instrument in Zār ensembles.

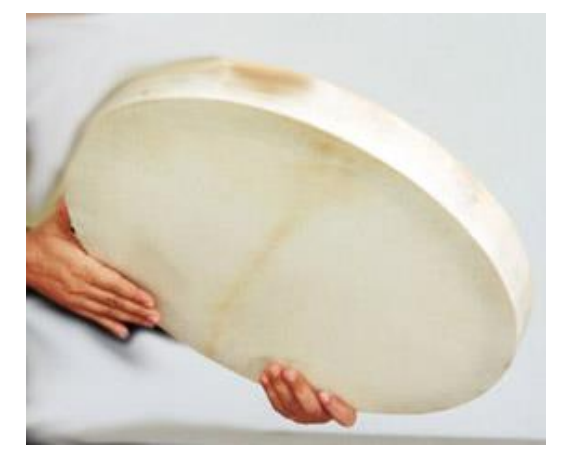

Figure (2) Duff (Tar)

Mazaher: the same as the $d u f f$, but its frame is provided with circular pieces of copper or tin.

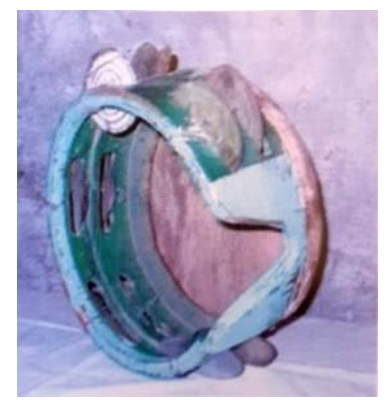

Figure (3) Mazaher (singular: Mezhar)

Hana: is a kind of drums and almost the same size as the regular mezhar but without the attached small jingles. Its frame width may increase up to $14 \mathrm{~cm}$, which is the reason behind its powerful sound. It is used mostly along with the mazaher to accent the main units of the beat. ${ }^{2}$

Tura/ cymbals: Circular pieces of copper or reinforced iron sheet with a diameter of up to $9 \mathrm{~cm}^{3}$

\footnotetext{
${ }^{1}$ Al-Ulaymi, Op. Cit. p.116

2 Mohammed Omran, Egyptian folk music instruments and tools. (Cairo: Egyptian Center for Culture and Art, 2007) p.37

${ }^{3}$ Ibid 1, P.74

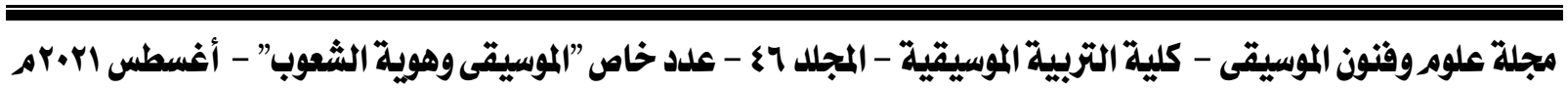




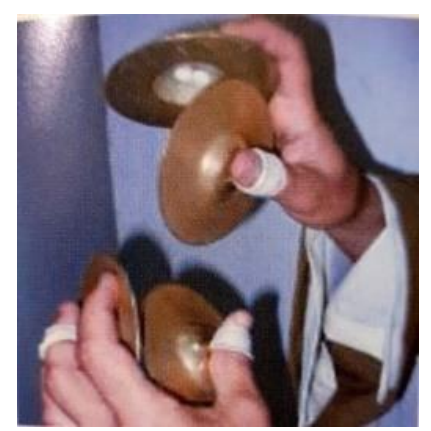

Figure (4) the Tiurra

Shakhāshīkh (maracas): They are made of tin cans or by using hollow wooden balls with wooden handles. The sound of rattling is made by placing an amount of pebbles inside of it. ${ }^{1}$

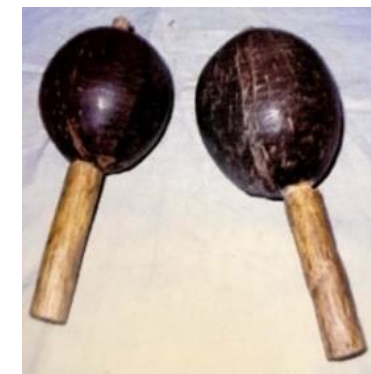

Figure (5) the Shakhāshīkh

Darabukka: A percussive instrument made of clay and has the shape of a goblet with a parchment of goat skin tightened on its wider side. ${ }^{2}$

Dohulla: is the bigger size of the darabukka (almost double the size)

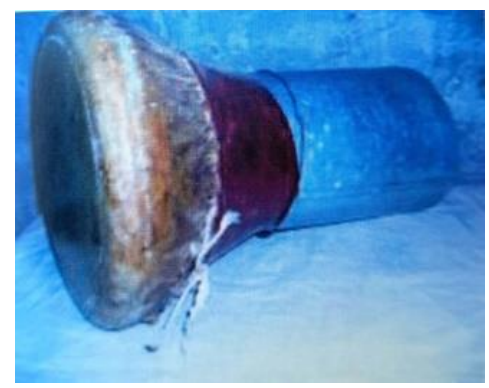

Figure (6) Dohulla

\section{2- Sudanese Zār}

${ }^{1}$ Ibid 1, P.77

${ }^{2}$ Omran, Op. Cit. P.41

مجلة علوم وفنون الموسيقى - كلية التربية الموسيقية - المجلد 7؟ - عدد خاص "الموسيقى وهوية الشعوب" - أغسطس ابr.r. 
Also called "Zār El Tanboura", it consists of a male leader called 'Sangak' who plays the main instrument, the Tambura, while singing the main phrases of the song. Some of the Zār songs that they perform are:

- Salila ya ward el-hamam

- Gado and Meram

- Gammal

Melodies in the music of Sudanese Zār are always in an Anhemitonic scale (pentatonic scale) and the intervals between the notes are narrow.

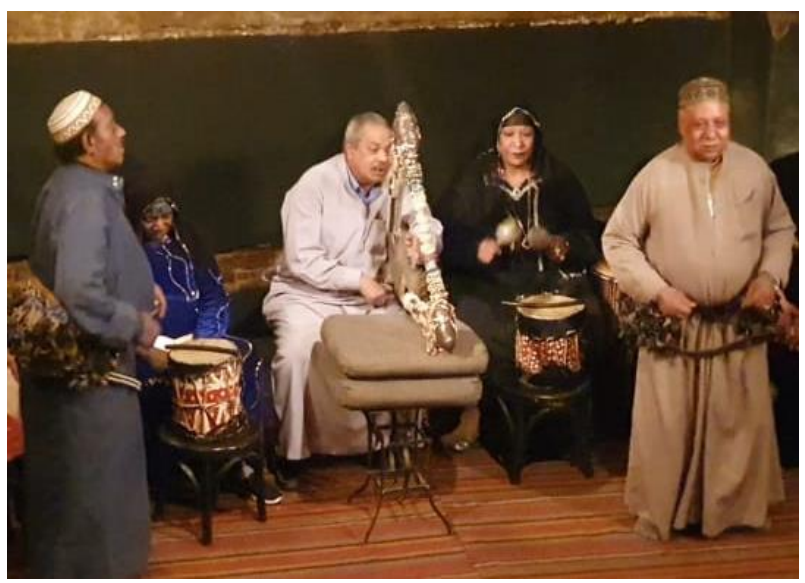

Figure (7) the main instruments of the Tambura Zār

\section{Musical Instruments}

Tambura: is a rectangular shaped string instrument. The strings vary between four to six strings made of Wire, nylon, or animal gut.

This instrument is considered sacred because people of the Zār believe that its sound has special powers to affect the Jinn, therefore, they treat it respectfully and should have its own place and it's not allowed to put anything on it. ${ }^{1}$ 


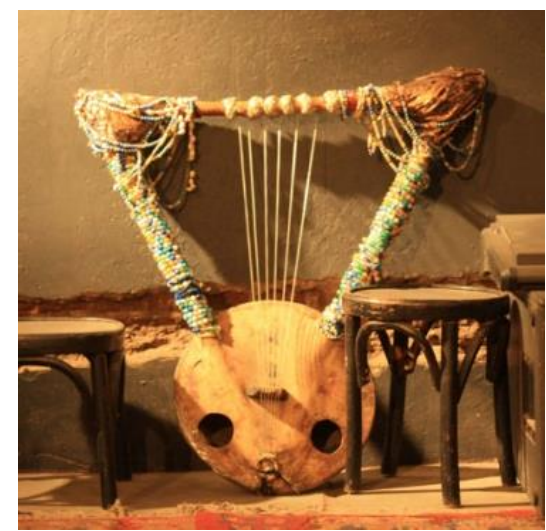

Figure (8) the old Tambura

Mangour: a leather belt - about $30 \mathrm{~cm}$ wide - with lots of goat hooves attached to it. It is worn around the west and by moving the west; the hooves hit each other making a very loud rattling sound. ${ }^{1}$

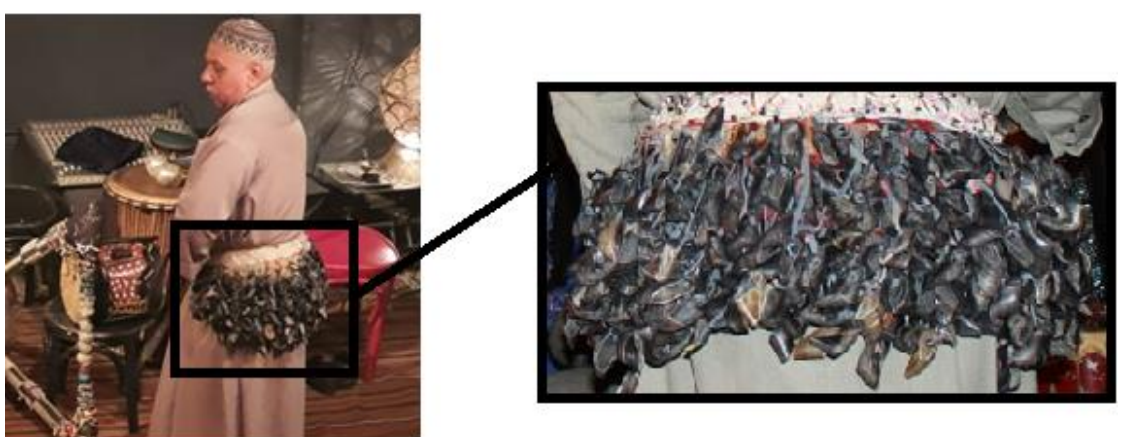

Figure (9) Araby one of Mazaher performers playing the Mangour

Sudanese/ Siwa drums: (also called Djun Djun) a type of African drums that is made out of wooden barrel with a cow skin head, held down with strong leather string. These drums come in three different sizes.

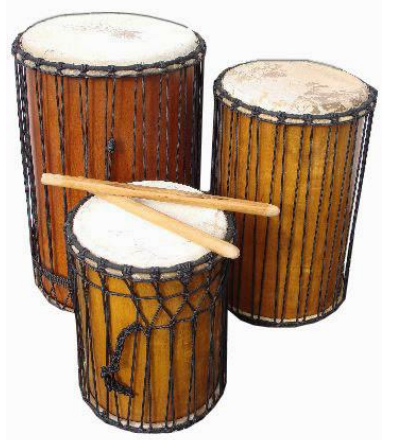

Figure (10) Sudanese drums

${ }^{1}$ Ibid 1, P.78

مجلة علوه وفنون الموسيقى - كلية التربية الموسيقية - المجلد 7؟ - عدد خاص "الموسيقى وهوية الشعوب" - أغسطس الr.rم 
Merwas/ Meroyas: is a small Sudanese drum, can be used as one drum or in pair. The player hits the leather of the drum with his hands. ${ }^{1}$

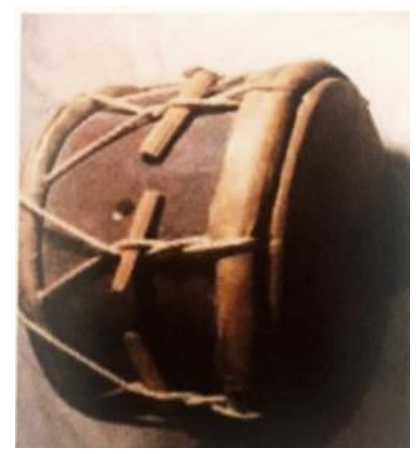

Figure (11) Merwas

Maracas "shakhāshīkh" are sometimes used in this type of Zār but it is not a main instrument in all performances.

\section{3- Abul Gheit Zār}

Zār Abul Gheit or Al Gheitānī, named after one of the most famous Sufi saints in the governorate of Qaliubiya, Sidi Abul Gheit, who has a shrine in a village carrying his name close to the town Qaliub. The Gheitānī texts are situated in the same context as the lyrics which characterize Islamic religious chants in general, i.e. between Dhikr (ritual invocation of God), Madị Al Nabi (praise of the Prophet) and Al Taghannī bi Karāmāt Al 'Awlīà' (commendation of the nobility of Sufi saints).

This type of Zār is therefore a model that helps us to understand the processes of mutual influence of different musical genres and their subjection to the social and religious transformations which peoples have experienced over the ages. ${ }^{2}$ The lead singer in this style is male, and all musicians sing the refrain of the song in response to the lead singer.

\footnotetext{
${ }^{1}$ Omran, Op. Cit. P.68

2 El-Maghraby, Op. Cit.
}

مجلة علومروفنوذ الموسيقى - كلية التربية الموسيقية - المجلد 7؟ - علد خاص "الموسيقى وهوية الشعوب" - أغسطس ابr.rم 


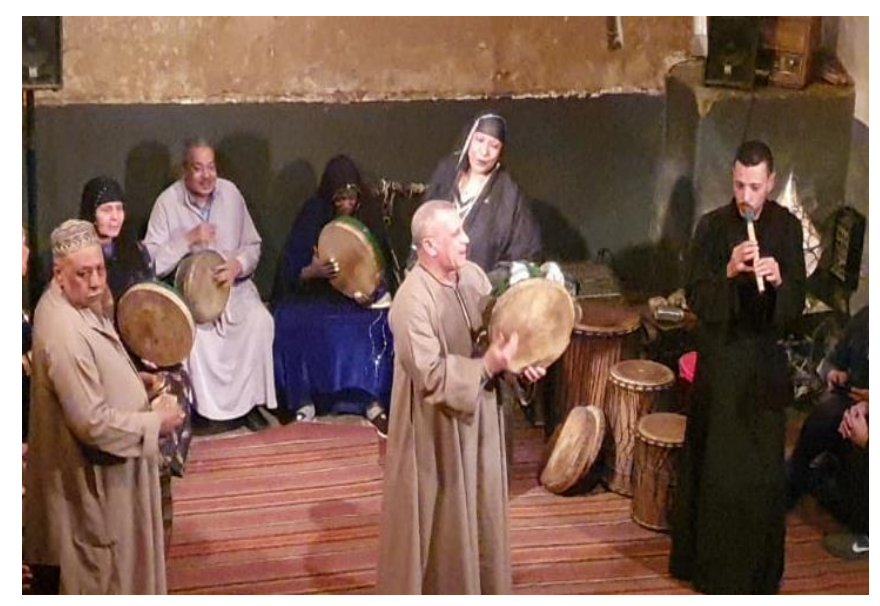

Figure (12) the complete ensemble for Abul Gheit Zār

\section{Musical Instruments}

This type of Zār depends on a woodwind instrument called kawāla or sollamiya as well as percussion instruments: duhulla, tūra and mazaher.

Kawala: A hollow reed consisting of four knuckles, with six holes in a straight line. It has twenty-four different sizes that vary in length and diameter.

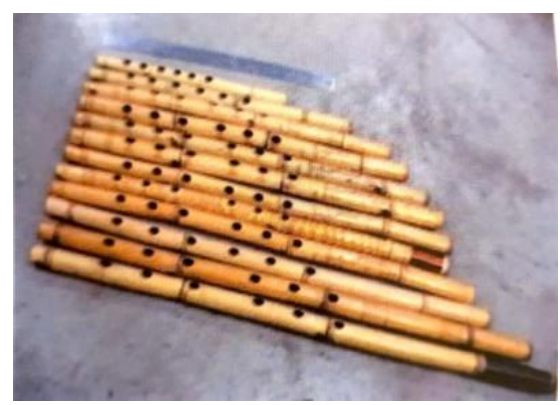

Figure (13) the different sizes of Kawala

\section{Second Section: Analytical Framework}

The researcher chose (Yawra Bey) one of Upper Egyptian Zār songs performed by Mazaher, which represents the common characteristics of Zār music.

مجلة علوم وفنون الموسيقى - كلية التربية الموسيقية - المجلد ج؟ - عدد خاص "الموسيقى وهوية الشعوب" - أغسطس ا.r.rم 


\section{Yawra Bey}

This song is a common Zār song in all ceremonies. Yawra is one of the most famous Jinn in Zār and he is known as "king of lovers". His name is always associated with Pasha or Bey ${ }^{1}$.

\section{Form, Melody \& Tonality}

- The song is characterized with the similarity in tunes, they sound like one melody for almost all the song but with slight variations and different lyrics.

- The melody is based on a motive consisting of one small phrase that is constantly repeated. This motive revolves around five notes starts with note (G) and followed by Bayāti tetrachord starting on (A) as shown in the following figure:

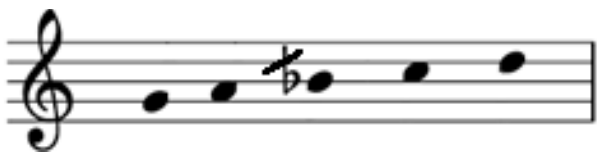

Figure (14) Tonality - Yawra Bey song

- One performer in particular is adding a heterophonic ${ }^{2}$ touch to the song by changing the $\left(\mathrm{B}^{\mathrm{b}}\right)$ into $\left(\mathrm{B}^{\mathrm{b}}\right)$ creating a clear dissonance in the tune.

- The song starts with an ad libitum intro where the performer has the freedom to vary the notes or tempo.

- The intro consists of two singing phrases. The first phrase is sung by the soloist (omm Sameh) then the chorus ladies answer that phrase with a longer one. The second phrase is sung entirely by the soloist. This antiphonic style distinguishes the performance in Zār songs.

\footnotetext{
${ }^{1}$ Pasha (paşa) and Bey (Beck) are official honorific titles of Turkish origins, meaning the master, the great, or lord.

${ }^{2}$ Heterophony is the simultaneous performance of the same melodic line, with slight individual variations, by two or more performers
}

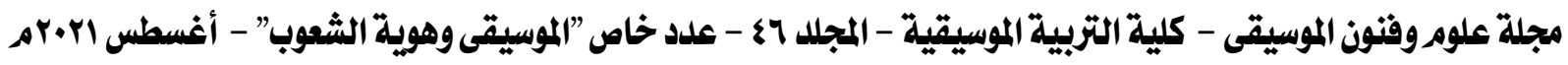


The following notation is the main skeleton of the song

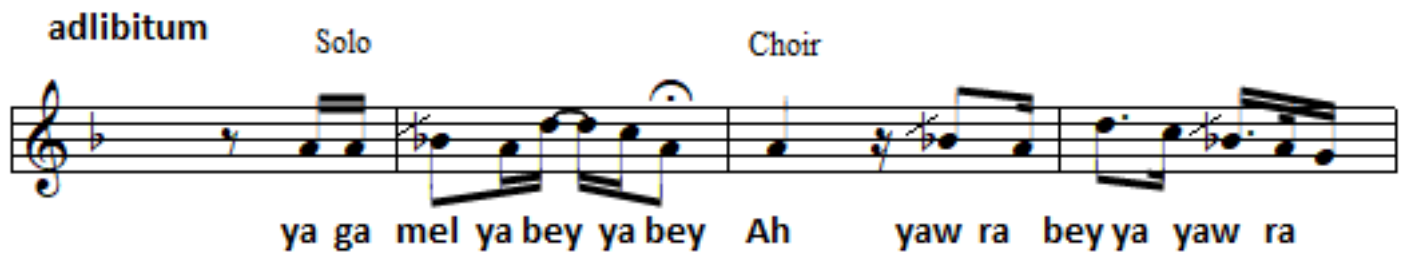

ya ga mel ya bey ya bey Ah yaw ra bey ya yaw ra
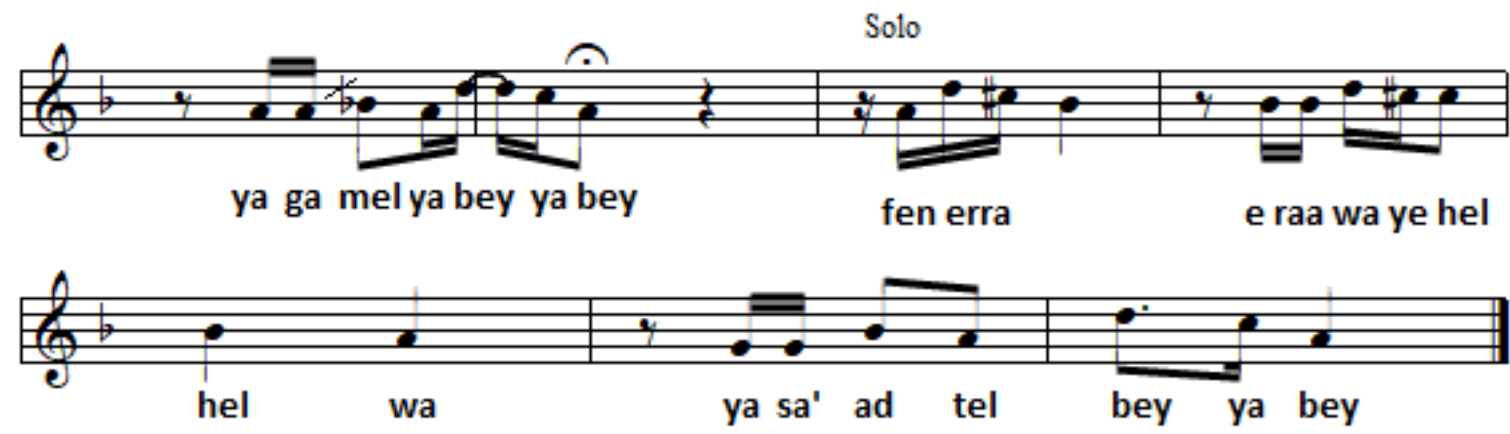

Figure (15) Intro - Yawra Bey song

- The whole song- like any other Zār song- is based on repetition; the main phrase of the song consists of Couplet (sung by the soloist) and Mazhab (a verse sung by the chorus ladies), it is repeated 11 times with slight changes and different lyrics, and takes around 3 minutes of the performance.

Andante moderato
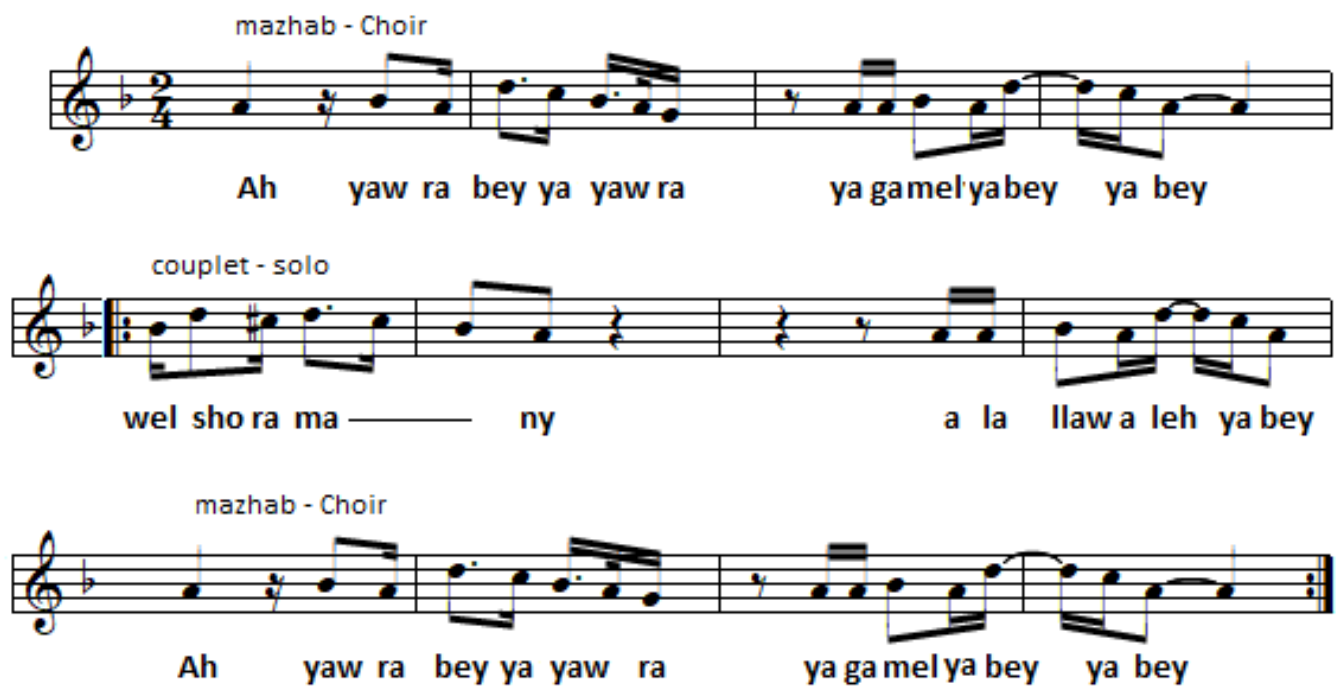

Figure (16) Couplet and Mazhab - Yawra Bey song

مجلة علوم وفنون الموسيقى - كلية التربية الموسيقية - المجلد 7؟ - علد خاص "الموسيقى وهوية الشعوب" - أغسطس اYr.rA 
- Almost near the end of the performance- melodic phrases become shorter which gives the feeling of acceleration, and performance gets more antiphonic. Figure 17 shows a phrase that is repeated 10 times and takes around a minute:

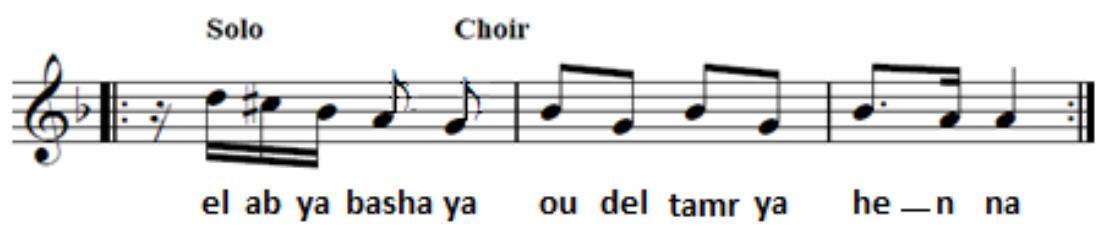

Figure (17) shorter melodic phrases - Yawra Bey song

- Previous figure shows the ending of the performance with a shorter phrase that is repeated 13 times. This phrase starts to accelerate in tempo at the $6^{\text {th }}$ repetition and fades out when the drumming begins to get louder.

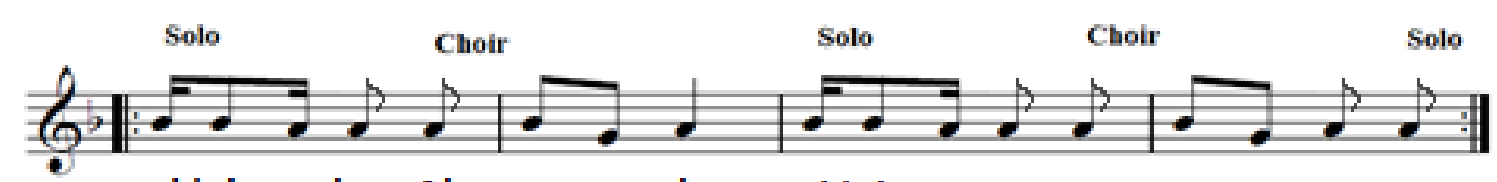

el 'ab ya bey Ah yaw ra bey el 'ab ya basha ah yaw ra bey

Figure (18) the ending melodic phrase - Yawra Bey song

\section{Rhythm}

- The clear and strong loud rhythm plays an important and fundamental role in the Zār music. The contrast between strong beats and week beats is very clear.

- Percussion instruments that are used in this song are: two Duffs, Dohulla, Toura, Mezhar, and Sudanese Drums. Percussions start at second 24 and play continuously until the end of the song.

- The main beat of this song is Malfouf, and it's played by Duffs. The rest of the instruments are playing variations over the main beat.

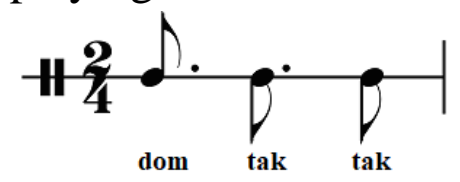

Figure (19) Malfouf beat

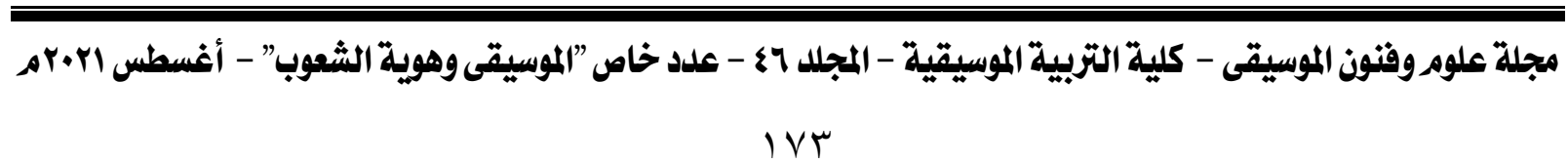




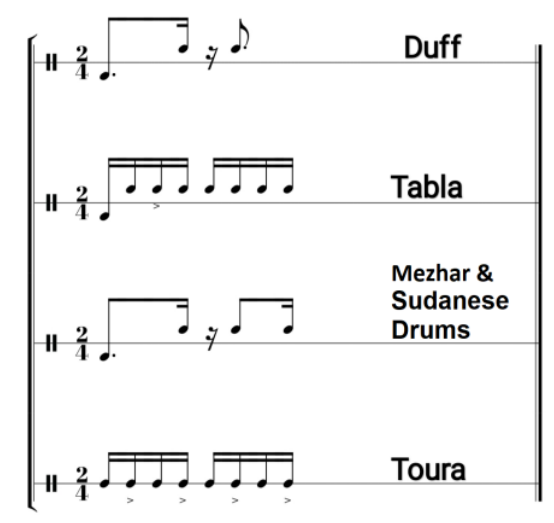

Figure (20) Rhythmic patterns- Yawra Bey song

- The tempo remains stable on $(d=69)$ from the beginning till minuet 5:40, then the speed starts accelerating till the song ends with the tempo $(d=$ 80).

- The ending of the song is one minute of loud drumming. The kodya and the player of Sudanese drums also held the Duffs and played very accented and polyrhythmic beats along with the other performers.

- In Zār songs, the peak of the song is always at the end, and there is no specific time for that peak; performers reach the climax of the song when they feel it. The accelerating tempo and the intense singing and drumming are the culmination of the song and it's when the listener/ patient reaches the state of trance.

\section{Healing in Zār Ritual}

Listening to the music of Zār in all its styles is very effective, although scientifically it cannot be explained from spirits perspective. When listening to the music of Zār, Somehow the rhythmic sounds grab control of the brains of everyone who are listening, forcing them to operate simultaneously and perform the same behaviors in synchrony. It is simply the power of music to tap into brain circuits controlling emotion and movement.

In my opinion, to explain how drumming in Zār ceremonies makes everyone interact and dance, we need to understand the concept of entraining.

The process of entraining in the context of psychoacoustics is the process of affecting brain waves, breathing, and heart rate by changing their speed higher or lower. The factor behind this process is rhythm, which is a very powerful

مجلة علوم وفنون الموسيقى - كلية التربية الموسيقية - المجلد جا؟ - عدد خاص "الموسيقى وهوية الشعوب" - أغسطس اr.rم 
element that can change the natural frequency of an object to match this rhythm ${ }^{1}$.

The effect of rhythm on the human body occurs in two directions; the first direction is an external effect and occurs when exposed to a specific rhythm that changes the speed of the brain waves. The second direction is the internal effect that occurs due to the change of the brain waves, which in turn affects and changes the speed of breathing and the speed of the heartbeat.

Rhythm implies entrainment, so the beat is related to the desired rate of internal pulses. The music of Zār in that case is not about consonance and dissonance; it is about sonic density and the effect of data on the nervous system.

Kay Gardner in his book "Sounding the Inner Landscape: Music as Medicine" identifies the therapeutic elements of music, these elements simply meet the characteristics of Zār music ${ }^{2}$.

1-Drone: A drone is a long uninterrupted sound, or set of sounds, underneath the music. Drone tones are usually long and low, but in Zār music, drone could be the bass ostinato effect of a repeated background rhythmic pattern from a drum, or that nonstop performance on the tambura behind the melody lines of the singing.

2- Repetition: when a musical phrase is repeated, the listener becomes comfortable. Repetition creates a hypnotic or relaxing effect in which the listener is moved into receptive state. Repetition with rhythmic pattern or simple melodic phrases can create a trance state, and this is exactly the main element in Zār music and drumming.

3- Rhythm: it is the energy of music, and it's what gives energy to the body. ${ }^{3}$ The effect of rhythm springs from the natural reaction of pulses in the body: heartbeat, breath cycle, brainwaves. According to the concept of entrainment, stronger rhythmic vibrations affect weaker ones, so when the tempo accelerates with that intense beating (like in Zār) it accelerates these pulses as well.

\footnotetext{
${ }^{1}$ Wayne Perry, Sounding Medicine. (New jersey: New Page Book, 2007) p.203 - 205

${ }^{2}$ Leeds, Joshua. The Power of Sound. (Vermont: Healing Arts Press, 2001), P.154 - 157

${ }^{3}$ Costas I. Karageorghis, Applying Music in Exercise and Sport, (US: Human Kinetics, 2016) p.6
}

مجلة علوم وفنون الموسيقى - كلية التربية الموسيقية - المجلد ج؟ - عدد خاص "الموسيقى وهوية الشعوب" - أغسطس ا.r.rم 
4- Harmony: with the use of inner harmonic phrases, dissonance resolves to consonance and the tension is released. Complex harmony challenges the listener emotionally. As in Zār music, the rich sonic blend between the different lines from each performer creates that complex harmonic structure.

5-Melody: the power of melody is its ability to take away the listener from physical awareness. Melody has been prescribed as anesthesia because of its power of soothing. The short repeated phrases of melody in Zār music makes them distinctive and memorable, therefore, it can easily be emotionally linked to the desired effect and feeling.

6- Instrumental colors: the timbre of each instrument is determined by the uniqueness of its harmonic content. Drums are mostly the main and common instruments in Zār music with all its styles, and while each instrument resonate the listener in a specific area of the body, drums resonate the whole body.

7- Form: form is the organization of a composition. The form of Zār music is usually verse, verse, chorus, verse, chorus, verse, chorus, till the end of the song with vigorous music and drumming. This non-changing form provides a sense of stability.

8- Intents: the most important element in therapeutic music is the intention of the musical team. And perhaps it is the intention and beliefs of the patient are what make the healing music be effective, while resistance can hinder the whole process.

Zār is an ancient art, a ceremony that helps people deal with their negative feelings and convert them into safe and harmless paths. The healing Zār music is one of our Egyptian folklore heritages that must be preserved and revived.

Zār is nothing but an emotional and psychological discharge. It is the emptying of suppressed energies, unleashing them under the influence of the intense beats of Zār. The atmosphere of songs and drumming filled with the smell of incense only aims to achieving a state of general psychological balance.

مجلة علوم وفنون الموسيقى - كلية التربية الموسيقية - المجلا r؟ - عدد خاص "الموسيقى وهوية الشعوب" - أغسطس ا.r. 


\section{Results}

After studying the music of Zār as a cultural ritual in Egypt, the research questions can be answered as followed:

\section{1- What is Zār?}

Zār is an Amharic word refers to both type of spirit and to various practices and rituals associated with those spirits. It is a healing ritual that aims to create harmony between the possessed person and her "master".

\section{2- What are the main features of Zār music and songs?}

- The song of the Zār is a "calling" for someone (the spirit) so the phrases are usually short and simple but repeated. The song lyrics are used as a communication tool; they are centred on describing the spirits, their belongings and tools, and their personalities.

- Rhythm is the most dominant element in Zār music, and practitioners are using different types of drums in the ritual. Rhythm often starts in a calm and simple way, but as the song is repeated and the rite reaches its climax, the rhythms intensify and counter rhythm become richer; the players seem to become more free and open. This repetition of drumming and singing is designed to induce a trance state. The chosen rhythms should be compatible with the possessing master.

- The music of the Zār is circular, using one simple short melody repeated through the song. Some of the songs may start with a briefed introduction, and some of them end with a certain ending of a repeated sentence.

\section{5- How did Mazaher ensamble manage to transform the "Zār" from a therapeutic ceremony into a Musical Ritual?}

Mazaher ensemble transformed the therapeutic ritual of Zār into a musical concert inspired by the three styles of the Zār that was practiced in Egypt; Upper Egyptian Zār, Sudanese or African Zār, and Abul Gheit Zār. They perform a chosen number of songs every Wednesday at "Makan" in a form of a public concert.

They scrapped the round tall table in the center of the place, candles, and the use of costumes and acting, keeping only the use of incense at the beginning

مجلة علوم وفنون الموسيقى - كلية التربية الموسيقية - المجلا جا؟ - عدد خاص "الموسيقى وهوية الشعوب" - أغسطس ا.r.rم 
of the show as in the original ritual. They perform their regular songs but without any offerings to the spirit, and dancing are much lighter, like simple movements by one of the chorus singers or some decent shoulder shakes by the leader.

\section{3- What are the characteristics of Zār music that causes the state of trance?}

The healing capabilities in Zār music can be found in its characteristics. These therapeutic elements lie in:

1- Drone: can be found in the effect of a repeated background beat from a drum, or the nonstop performance on the Tambura behind the melody lines of the singing.

2- Repetition: the musical phrase is repeated constantly, this repetition creates a hypnotic or relaxing effect in which the listener is moved into receptive state.

3- Rhythm: According to the concept of entrainment, stronger rhythmic vibrations affect weaker ones, so when the rhythm accelerates with that intense beating (like in Zār) it affects the whole body.

4- Harmony: the rich sonic blend between the different lines from each performer creates a complex harmonic structure.

5- Melody: The short repeated phrases of melody in Zār music makes them distinctive and memorable, therefore, it can easily be emotionally linked to the desired effect and feeling.

6- Instrumental colors: Drums are mostly the main and common instruments in Zār music with all its styles, and while each instrument resonate the listener in a specific area of the body, drums resonate the whole body.

7- Form: The form of Zār music is usually verse, verse, chorus, verse, chorus, verse, chorus, till the end of the song with vigorous music and drumming. This non-changing form provides a sense of stability.

8- Intents: the intention and beliefs of the patient are what make the healing music be effective.

مجلة علوم وفنون الموسيقى - كلية التربية الموسيقية - المجلل ج؟ - عدد خاص "الموسيقى وهوية الشعوب" - أغسطس آr.rم 


\section{Recommendations}

- Zār is a type of folk art that can be evolved into acting, singing, and music to form a kind of musical theater, and by this we can revive the folklore heritage of Zār and present it in an acceptable way to the society.

- The elements of Zār rituals such as music, drumming, dancing, and acting, should be studied scientifically to prove the psychological and physical therapeutic capabilities in it.

- Attention must be paid to recording and notating the songs and music of the Zār in order to prevent their loss or obliteration.

- Forming a team of researchers based on various disciplines for studying Zār in all its aspects.

- Encouraging the presentation of Zār ceremonies as public ceremonies that help to remove ambiguities in the practice of its rituals.

مجلة علوم وفنون الموسيقى - كلية التربية الموسيقية - المجلد ج؟ - عدد خاص "الموسيقى وهوية الشعوب" - أغسطس ا.r.م. 


\section{Bibliography}

1. Al-Ulaymi, Adil. al-Zār wa masrah al-tuqus. (Cairo: General Egyptian Book Organization, 1993)

2. APA Dictionary of Psychology (Washington: American Psychological Association 2020), "Trance", https://dictionary.apa.org/trance

3. Aspen, Harald. Amhara Traditions of Knowledge: Spirit Mediums and Their Clients. (Wiesbaden: Otto Harrassowitz Verlag, 2001)

4. Beeman, William O., The Zār in the Persian Gulf Performative dimensions, Anthropology of the Contemporary Middle East and Central Eurasia $\cdot$ December 2015. P.3

5. Behrend, Heike. Spirit Possession, Modernity \& Power in Africa (Madison: The university of Wisconsin Press, 1999)

6. El-Aswad, El-Sayed. Religion and Folk Cosmology: Scenarios of the Visible and Invisible in Rural Egypt (Greenwood Publishing Group, 2002)

7. El Hadidi, Hager. Zār: Spirit Possession, Music, and Healing Rituals in Egypt, (Cairo: The American University in Cairo Press, 2016)

8. El Maghraby, Ahmed. My journey with the Zār People and Mazāher Ensemble (cairo: Egyptian Center of Culture and Art, 2020)

9. Fahmy, Azza. Enchanted Jewelry of Egypt: The Traditional Art and Craft. (American University in Cairo Press, 2007)

10.Fakhouri, Hani. The Zār Cult in an Egyptian Village. Anthropological Quarterly Vol. 41, No. 2 (Apr., 1968)

11.Gaunor, Mitchell L., The Healing Power of Sound. (London: Shambhala, 2002)

12.Isenberg, Charles William, Johann Ludwig Krapf, James MacQueen, Journals of the Rev. Messrs Isenberg and Krapf, Missionaries of the Church Missionary Society: Detailing Their Proceedings in the Kingdom of Shoa, and Journeys in Other Parts of Abyssinia, in the Years 1839, 1840, 1841, and 1842. (Cambridge University Press, Oct 27, 2011)

مجلة علوم وفنون الموسيقى - كلية التربية الموسيقية - المجلل ج؟ - عدد خاص "الموسيقى وهوية الشعوب" - أغسطس الr.rم 
13.Laycockm, Joseph P. Spirit Possession around the World: Possession, Communion, and Demon Expulsion across Cultures (California: ABCCLIO, 2015)

14.Leeds, Joshua. The Power of Sound. (Vermont: Healing Arts Press, 2001) 15.Karageorghis, Costas I. Applying Music in Exercise and Sport, (US: Human Kinetics, 2016)

16.Khalifa, Najat, and Tim Hardie. "Possession and jinn." Journal of the Royal Society of Medicine vol. 98,8 (2005): 351-3. doi:10.1258/jrsm.98.8.351

17.Natvig, Richard. "Oromos, Slaves, and the Zār Spirits: A Contribution to the History of the Zār Cult." The International Journal of African Historical Studies 20, no. 4 (1987): 669-89. Accessed January 19, 2021. doi:10.2307/219657.

18.Omran, Mohammed. Egyptian folk music instruments and tools. (Cairo: Egyptian Center for Culture and Art, 2007)

19.Perry, Wayne. Sounding Medicine. (New jersey: New Page Book, 2007)

20.Reese, Scott. Imperial Muslims: Islam, Community and ity in the Indian Ocean, 1839-1937. (Edinburgh: Edinburgh University Press, 2018)

21.Toggia, Pietro. Abebe Zegeye, Ethiopia in Transit: Millennial Quest for Stability and Continuity. (New York: Routledge, 2011)

22.The ritual - https://egyptmusic.org/en/Musicians/mazaher/

مجلة علوم وفنون الموسيقى - كلية التربية الموسيقية - المجلد ج؟ - عدد خاص "الموسيقى وهوية الشعوب" - أغسطس ا.r.rم 


\begin{abstract}
Zār ceremonies are used to heal individuals who are possessed by spirits or as called in Egypt "Jinn". When bad spirits inhabit a person, they are believed to remain with the hosts forever, inducing erratic behavior every few months or years. Zār is a healing ritual that is mostly led by women drumming, Singing and dancing to heal the possessed person. At the peak of that ritual, the possessed person goes through a trance that transforms him from the physical world to the spiritual world.

The practiced ritual of Zār became limited in its content, many songs have been forgotten and the practice of Zār in Egypt has nearly vanished. Only few persons within greater Cairo still have knowledge of the musical legacy of the Zār. In the whole of Egypt only around 25 people continue to practice this knowledge and this tradition.

Mazaher ensemble is one of the famous ensembles in Egypt that continues to uphold the traditions of the Zār by performing the vigorous singing and dancing routine, although in a performative context, without demons being evicted. Mazaher ensemble is remarkably performing the Zār every week with powerful Sufi singing and rich poly-rhythmic drumming.

The researcher will attend their performances to address how they transformed the therapeutic ritual of Zār into a pure musical ceremony, with adding a whole new perspective to the musical elements of that ancient folkloric ritual.
\end{abstract}

Keywords: Zār, musical heritage, Egyptian Culture, folk Rituals, reconciliation rite.

مجلة علوم وفنون الموسيقى - كلية التربية الموسيقية - المجلد جا - عدد خاص "الموسيقى وهوية الشعوب" - أغسطس اr.rم. 


\section{تحول "الزار" من طقس علاجي لطقس موسيقي عذد فرقة مزاهر}

\section{مروة يوسف الصياد*}

تُتخدم طقوس الزار لطرد القرين الذي يتملك الثخص أو كما يطلق عليه في مصر "الجن". عندما يقترن ذلك القرين شخص ما، فإنه من المُعتقد أنه يظل مع ذلك الثخص إلى الأبد ، مما يؤدي إلى ظهور

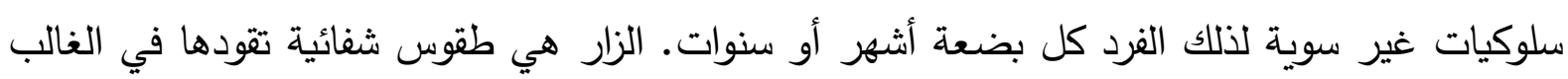

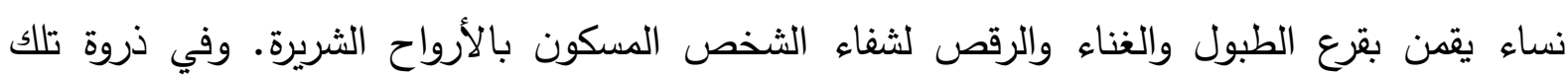

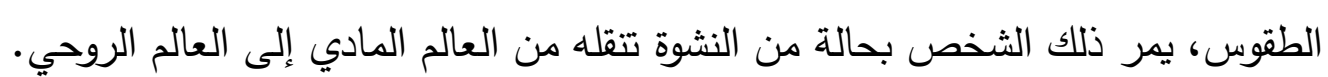

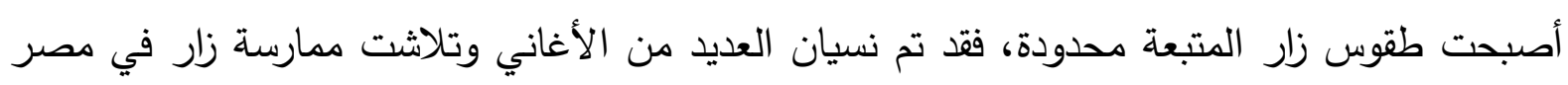
تقريباً. قلة قليلة فقط من الأشخاص داخل القاهرة ما زالوا على معرفة بذلك الإرث الموسيقي للزار بينما يوجد حوالي م شخصاً فقط في جميع أنحاء مصر مازالوا يمارسون تلك التقاليد والطقوس. فرقة مزاهر هي واحدة من أشهر الفرق في مصر والتي تستمر في دعم تقاليد الزار من خلال أداء روتين

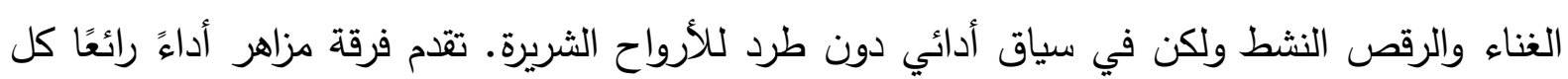
أسبوع مع الغناء الصوفي القوي والطبل الغني ذو التعدد الإيقاعي. ستفوم الباحثة بحضور عروض فرقة مزاهر للوقوف على كيفية تحويلهم للطقوس العلاجية للزار إلى دولى حفل موسيقي خالص، وإضافة منظور جديد بالكامل للعناصر الموسيقية لذلك الطقس الثعبي القديم.

الكلمات المفتاحية: الزار ، التراث الموسيقي ، الثقافة المصرية ، الطقوس الثعبية ، طقوس المصالحة.

"مدرس دكتور بقسم النظريات والتأليف - شعبة تأليف - كلية التربية الموسيقية جامعة حلوان"

مجلة علوم وفنون الموسيقى - كلية التربية الموسيقية - المجلا جا؟ - عدد خاص "الموسيقى وهوية الشعوب" - أغسطس ا.r.rم 